\title{
Trans-Pacific Partnership (TPP) as a US Strategic Alliance Initiative under the G2 System: Legal and Political Implications*
}

\author{
Eric Yong Joong Lee**
}

\begin{abstract}
"The rise of China" is a critical issue of the twenty-first century's world politics. China is leading the new bipolar system in the post-Cold War period with the US. As the American dominance in East Asia became weaker, the old containment could not be fully implemented anymore. As a result, a new comprehensive strategic initiative covering the whole Pacific coastal States is being adopted. The outcome of this transformation is the Trans-Pacific Partnership (TPP), which was reached on October 5, 2015. This article aims to analyze the newly arisen TPP as a post-Cold War strategic alliance of East Asia. The TPP is a mega regional trade agreement. Its predictable legal setting is thus indispensable for the peaceful coordination of competition between both sides. The TPP could be a firm ground for the stability of this region, sharing the vision of cooperation, not confrontation in the future.
\end{abstract}

\section{Keywords}

TPP, Containment, New Bipolar System, China, Mutual Defense Treaty, Pivot to Asia, One Belt, One Road Initiative, RCEP

The Trans-Pacific Partnership is perhaps the most ambitious trade negotiation underway in the world...

Our goal is for high standards for the Trans-Pacific Partnership to enter the bloodstream of the global system and improve the rules and norms.

US Vice President Joseph P. Biden, April 5, 2013

* This paper is a fully revised version of the presentation to the New Haven Conference held at Zhejiang University, China, on October 30-31, 2014.

** Professor of International Law at Dongguk University - Seoul, Korea; President of YIJUN Institute of International Law. B.A.(U. Washington), M.P.A.(Seoul N. U.), LL.M.(Leiden), Dr.iur.(Erasmus). ORCID: http://orcid.org/0000-0001-5640490X. This work was supported by the research program of Dongguk University. The views reflected in this article are his own. Readers' comments are cordially welcome. The author may be contacted at: grotian@hotmail.com / Address: 562 Gwangnaruro, Kwangjin-gu \#201 Seoul 143-821 Korea.

DOI: http://dx.doi.org/10.14330/jeail.2015.8.2.02 


\section{Introduction}

"The rise of China" is a highly topical issue of the twenty-first century's world politics. China is a pillar of the new bipolar (G2) system in the post-Cold War period with the US. Despite having been the central kingdom of the whole of Asia for thousands years, modern China's hegemony is a recent phenomenon. Before 1949, China had been occupied by foreign countries and then suffered from the civil war between the communists and the nationalists. Due to the Cold War, Chinese expansion to the Pacific coast was more severely restricted by the USled security alliance. Things began to drastically change in the new millennium. As the American dominance in East Asia became weaker, the old style of security alliance - containment - could not be fully implemented anymore. As a result, a new comprehensive strategic initiative covering the whole Pacific coastal States is being adopted. The outcome of this transformation is the Trans-Pacific Partnership ("TPP"), which was finally reached on October 5, 2015.

The primary purpose of this research is to analyze the newly arising question of the TPP as a post-Cold War strategic alliance of East Asia from the eyes of international law. This paper will pay more attention to the security alliance than a pure economic partnership. The TPP is a mega regional trade agreement ("RTA"). This strategic setting should be thus carefully analyzed from a legal and political perspective. In this paper, the author will discuss the grand institutional shift from the containment to the TPP from a viewpoint of the security initiative between member States beyond the implications of trade and an investment agreement. This paper is composed of four parts, including a short Introduction and Conclusion. Part two will examine the origin and East Asian evolution of the containment policy as a conventional security alliance led by the US. The legal structure of the policy will also be analyzed. Part three will discuss the legal and political implications of the TPP under the new bipolar system as a security initiative.

\section{A Conventional Security Alliance: The Containment Policy}

\section{A. Origin: Bar against the Soviet Union}

The postwar US-led strategic alliance was the containment, which was first implemented 
in Europe in the 1940s. The Containment Policy was initiated as an American doctrine to prevent the former Soviet Union from enlarging its hegemonic influence in Eastern Europe during the Cold War. ${ }^{1}$ The strategic identity of this policy was to 'block' the Soviet Union (communists) within its own influential area.

Figure 1: Containment in Europe in the Cold War period ${ }^{2}$

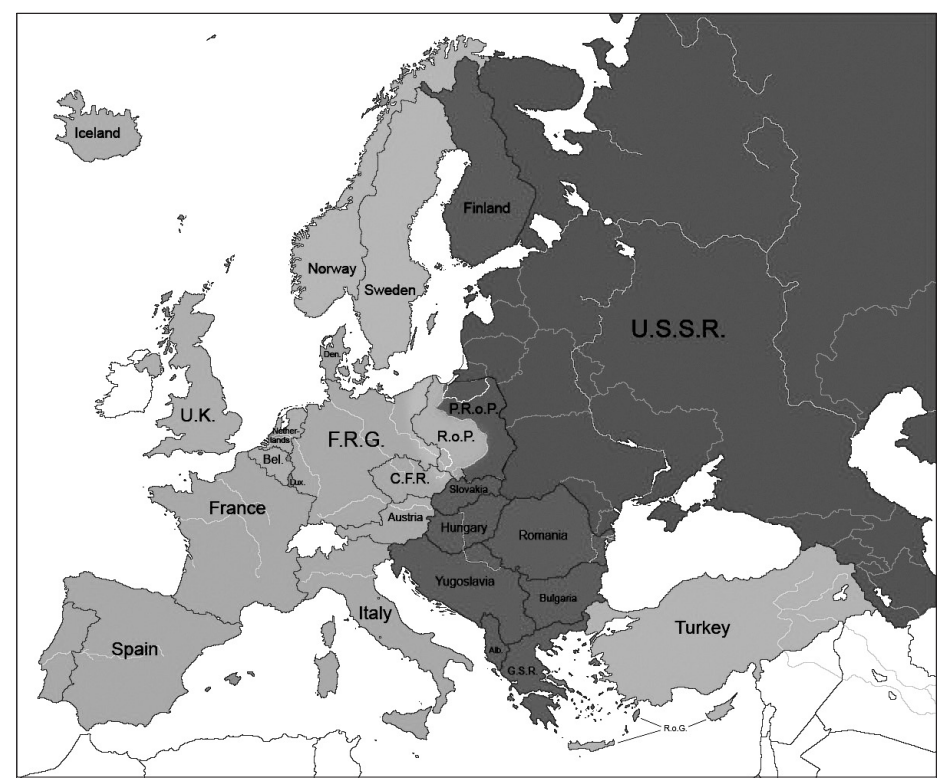

The 'containment' originated from a historic diplomatic cable (1946) by an American diplomat, George Kennan, working for the US Embassy at Moscow at the time; ${ }^{3}$ it was later published anonymously (pseudonym X) in the magazine ForeIGN AfFAIRS under the title The Sources of Soviet Conduct. ${ }^{4}$ In the X-article, Kennan maintained that:

1 US Dept. of State Office of Historian, Milestones 1945-1952: Kennan and Containment, 1947, available at https:// history.state.gov/milestones/1945-1952/kennan (last visited on Oct. 30, 2015).

2 See Alternate Cold War Scenario, available at http:/www.alternatehistory.com/discussion/showthread.php?t=136169 (last visited on Oct. 30, 2015).

3 As a description of US foreign policy, the word originated in a report Kennan submitted to US Defense Secretary James Forrestal. See US Dept. of State Office of Historian, George Kennan and Containment, available at https://history.state. gov/departmenthistory/short-history/kennan (last visited on Oct. 30, 2015).

4 X (G. Kennan), The Sources of Soviet Conduct, Foreign AfF. 271 (July 1947). 
In these circumstances it is clear that the main element of any United States policy toward the Soviet Union must be that of long-term, patient but firm and vigilant containment of Russian expansive tendencies. ${ }^{5}$

Such a policy, Kennan predicted, would "promote tendencies which must eventually find their outlet in either the break-up or the gradual mellowing of Soviet power."

The Containment Policy was controversial among the US administrations. President Harry Truman (1945-53) advocated it through the establishment of the North Atlantic Treaty Organization ("NATO"). President Dwight Eisenhower (1953-61), however, adopted the "roll-back doctrine"; he refused to intervene in the Hungarian Uprising of 1956. ${ }^{8}$ President Lyndon Johnson (1963-69) referred to containment in his decision regarding Vietnam. ${ }^{9}$ President Richard Nixon (1969-74) followed it for his détente under the auspices of Henry Kissinger, which finally led to the Strategic Arms Limitation Talks ("SALT"). ${ }^{10}$ In spite of some controversies regarding the policy for those administrations, during the Cold War, the containment was recognized as a basic US strategy against the communist expansion. ${ }^{11}$

\section{B. Containment in East Asia}

\section{Origin}

The Containment Policy was applied to East Asia from the early 1950s. It was implemented by connecting a series of mutual defense treaties between the US and other allies along the east coast of China, such as Japan, South Korea, the Philippines, Taiwan, the Southeast Asia Treaty Organization-Association of Southeast Asian Nations ("SEATO-ASEAN"), Thailand, and Singapore. They were linked as the defense belt. The main objective of East Asian containment was to supposedly bind China to her mainland.

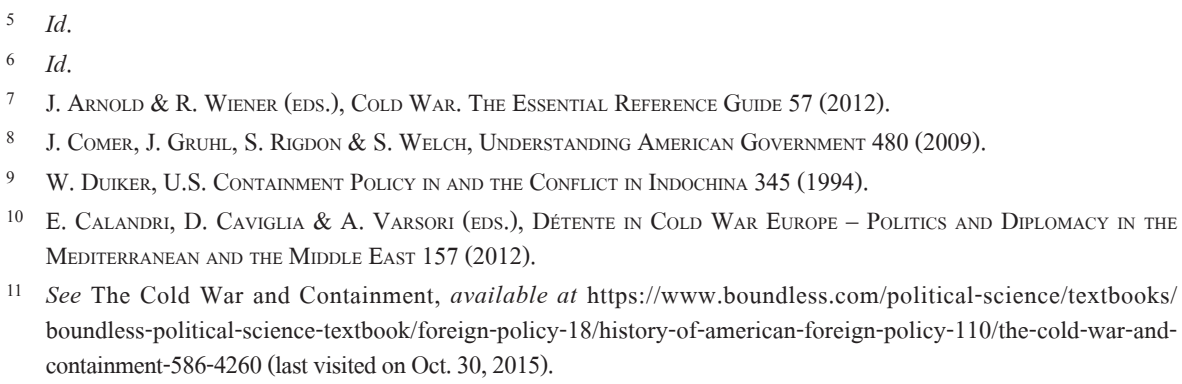

11 See The Cold War and Containment, available at https://www.boundless.com/political-science/textbooks/ boundless-political-science-textbook/foreign-policy-18/history-of-american-foreign-policy-110/the-cold-war-andcontainment-586-4260 (last visited on Oct. 30, 2015). 


\section{Legal Structure: Mutual Defense Treaties US-Philippines (1951)}

The Mutual Defense Treaty between the US and the Philippines was signed on August 30, 1951, in Washington, D.C. The document, consisting of eight articles, established support between the nations in times of a war-like crisis from an external third party. ${ }^{12}$ Under the US-Philippine Mutual Defense Treaty, an armed attack in the Pacific Area on either of the Parties would be recognized as dangerous to its own peace and safety. ${ }^{13}$ Accordingly, an armed attack on either of the Parties is deemed to include an armed attack on the metropolitan territory of either of the Parties. ${ }^{14}$

In 1998, the US and the Philippines signed a Visiting Forces Agreement ("VFA"), under which both nations regularly conduct the joint Balikatan military exercise to improve interoperability and combat readiness for counter-terror operations. ${ }^{15}$ In 2003, the US designated the Philippines as a major non-NATO ally. ${ }^{16}$

\section{US-South Korea (1953)}

The Treaty between the US and South Korea on account of mutual defense was signed on October 1, 1953, becoming effective in $1954 .{ }^{17}$ It established a covenant of the US for the defense aid of South Korea against any future attacks from North Korea. ${ }^{18}$ When the Korean War armistice talks were underway in early 1953, the then American President D. Eisenhower sought an amiable mode to establish a truce with North Korea by persuading the then South Korean president Syngman Rhee. President Rhee sought a mutual defense treaty with the US as a precondition of armistice. $^{19}$

12 See Mutual Defense Treaty between the US and the Republic of the Philippines of August 30, 1951, available at http:// avalon.law.yale.edu/20th_century/phil001.asp. For details, see T. Lum, The Republic of the Philippines and U.S. Interests, CRS Report RL33233 (Apr. 5, 2012), available at https://www.fas.org/sgp/crs/row/RL33233.pdf (all last visited on Oct. 30, 2015).

13 US-Philippine Mutual Defense Treaty art. IV.

14 Id. art. V.

15 B. Vaughn, U.S. Strategic and Defense Relationships in the Asia-Pacific Region, CRS Report RL 33821 (Jan. 22, 2007), at 23, available at http://fas.org/sgp/crs/row/RL33821.pdf (last visited on Oct. 30, 2015).

16 Id.

17 See Mutual Defense Treaty between the US and the Republic of Korea of October 1, 1953, available at http://avalon. law.yale.edu/20th_century/kor001.asp. For details, see U.S.-South Korea Mutual Defense Treaty, 6 ENCYCLOPEDIA OF World History: The Contemporary World, 1950 to the Present; Kongdan Oh, U.S.-ROK: The Forgotten Alliance, available at $\mathrm{http} / /$ www.brookings.edu/research/opinions/2008/10/south-korea-oh (all last visited on Oct. 30, 2015).

18 For details, see Seongwhun Cheon, North Korea and the ROK-U.S. Security Alliance, 34 Armed Forces \& Soc. 5-28 (2007).

19 See U.S.-South Korea Mutual Defense Treaty, supra note 17. For details, see W. StuecK (ed.), The KoreAn War IN WORLD HISTORY (2004); Foreign Relations of the US, 1952-1954. Korea (in two parts): vol. XV, pt. 2 (1984), available 
Following the new concept of 'strategic flexibility, ${ }^{, 20}$ America has recently repositioned and restructured her forces in South Korea. The concept involves the creation of more mobile units that can be deployed to crisis situations wherever they occur. $^{21}$ The deployment of US forces in South Korea in another area outside of the Korean peninsula is limited because the US-South Korea Mutual Defense Treaty confines the operational scope of US Forces in South Korea to the matters of the Republic of Korea. ${ }^{22}$ Today however, the operational scope of US Forces is rather extending out of the South Korean territory due to the new American strategy of mobile forces. It is also related to the highly critical issue on the wartime operational control of South Korean Forces.

\section{US-Taiwan (1954)}

The mutual defense treaty in 1954 between the US and Taiwan detailed that the US would protect Taiwan in the event of an invasion by mainland China (PRC). ${ }^{23}$ The treaty itself was a product of the American policy in the Cold War. The US was deeply concerned about communist expansions, as evidenced by the attack on prowestern South Korea by communist-driven North Korea in 1950. Subsequent to this, the Seventh Fleet was sent by the US in an effort to patrol the waters in the Taiwan Strait. $^{24}$

\section{SEATO and ASEAN (1954 \& 2005)}

Primarily a regional-defense organization from 1955 to 1977, the SEATO was created by the Southeast Asia Collective Defense Treaty. This treaty was signed on September 8, 1954 in Manila. The signatories included representatives from Australia, France, New Zealand, Pakistan, the Philippines, Thailand, the UK, and the

at https:/history.state.gov/historicaldocuments/frus1952-54v15p1 (last visited on Oct. 30, 2015).

20 For details on the concept of 'strategic flexibility,' see Soonkun Oh, The U.S. Strategic Flexibility Policy: Prospects for the U.S.-ROK Alliance, Master of Arts Thesis submitted to US Naval Postgraduate School 13-6 (2006), available at http://www.dtic.mil/dtic/tr/fulltext/u2/a462724.pdf (last visited on Oct. 30, 2015).

21 Supra note 15 , at 22.

22 Korea-US Mutual Defense Treaty art. IV.

23 US-Taiwan Mutual Defense Treaty of December 2, 1954, available at http://avalon.law.yale.edu/20th_century/chin001. asp (last visited on Oct. 30, 2015).

24 See Mutual Defense Treaty between the United States of America and the Republic of China, available at http:// www.taiwandocuments.org/mutual01.htm (last visited on Oct. 30, 2015). For details, see U.S.-Taiwan Mutual Defense Treaty, 6 Encyclopedia of World History: The Contemporary World, 1950 to the Present; L. Gordon, US Opposition to Use of Force in the Taiwan Strait, 1954-1962, 72:3 J. Am. Hist. (Dec. 1985); D. GrafF \& R. Higham, A Military History of China. (2002); E. Snyder, The Taiman Relations Act and the Defense of the Republic of China (1980); and N. Tucker, Dangerous Strait: The U.S.-Taiwan-China Crisis (2005). 
US. On February 19, 1955, the treaty came into force. ${ }^{25}$ However, Pakistan withdrew its support in 1968, and France suspended financial support in 1975. The final exercise of the organization was held on February 20,1976, and formally ended on June $30,1977 .^{26}$

Figure 2: Mutual Defense Treaties between US and East Asian Allies

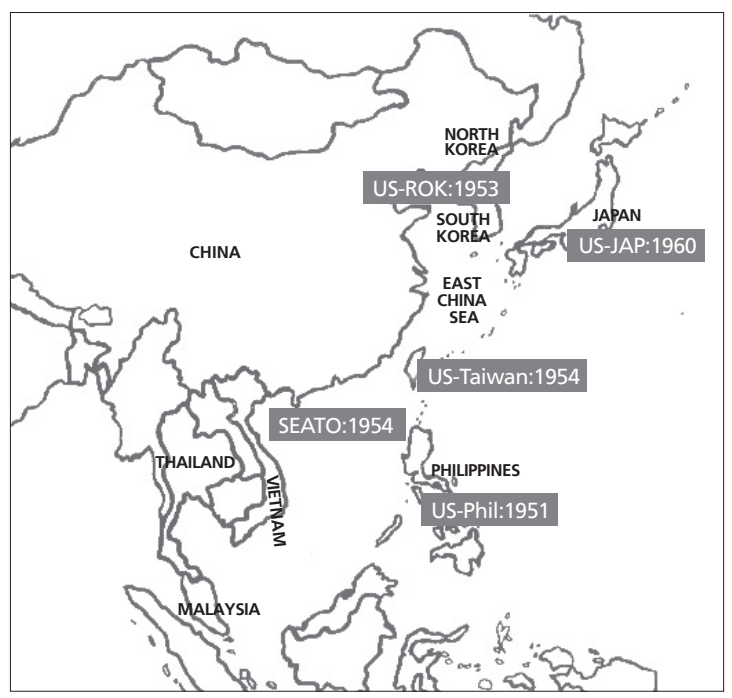

The SEATO was followed by the US development of the mutual security alliance with the ASEAN. ${ }^{27}$ Since 9/11, however, the American policy regarding Southeast Asia has largely focused on counter terrorism. ${ }^{28}$ American diplomacy is seeking to broaden her engagement with the ASEAN under a new initiative. ${ }^{29}$ The US-ASEAN

25 See SEATO Britannica Encyclopedia, available at http://global.britannica.com/EBchecked/topic/556523/SoutheastAsia-Treaty-Organization-SEATO. For details, see Foreign Relations of the US, 1952-1954: East Asia and the Pacific (in two parts): vol. XII, pt. 1 (1984), available at https://history.state.gov/historicaldocuments/frus1952-54v12p1 (all last visited on Oct. 30, 2015).

26 Britannica Encyclopedia, id.

27 Minda Calaguian-Cruz, Developments in ASEAN-U.S. Relations, in ASEAN-U.S. Relations: What are the TalKing PoINTS? 11 (Pavin Chachavanpongpun ed., Institute of Southeast Asian Studies of Singapore, 2012).

28 For details on counter-terrorism, see E. Tembo, US-UK Counter-Terrorism after 9/11: A qualitative apProach 1-3 (2014); B. Hoffman, 25 Rethinking Terrorism and Counterterrorism since 9/11 303-14 (2002), available at http:// www.amazon.co.uk/US-UK-Counter-Terrorism-after-qualitative-Contemporary/dp/0415643783; Counterterrorism after 9/11, available at http://www.academia.edu/518852/Counterterrorism_after_9_11 (all last visited on Oct. 30, 2015).

29 D. Mauzy \& B. Job, U.S. Policy in Southeast Asia: Limited Re-engagement after Years of Benign Neglect, 47 AsIAN SuRVEY 622-41 (July/August 2007), available at http://www.hks.harvard.edu/fs/pnorris/Acrobat/Burma_Mauzy_Job. 
Enhanced Partnership initiative was launched in November 2005 in order to 'foster cooperation,' which also included military cooperation. ${ }^{30}$ This partnership includes political, security, economic, social, and educational cooperation. ${ }^{31}$ In its efforts to boost these, the US not only maintains a security alliance with Thailand, but also imbibes with Singapore and Indonesia, which are strategic relationships. ${ }^{32}$

\section{US-Japan (1951 \& 1960)}

Signed on January 19, 1960, the treaty of mutual defense replaced the security treaty signed on September 8, 1951. ${ }^{33}$ The new treaty establishes that an armed attack against either Party in territories under Japanese administration is dangerous to its own peace and safety. ${ }^{34}$ It also states that they should work toward facing common danger in accordance with the relevant constitutional provisions and processes. ${ }^{35}$ The US-Japan security alliance is at a turning point regarding the newly arising issue of Japan's right to collective security, which is inconsistent with the principle of Article 9 of the Japanese Constitution. ${ }^{36}$

\section{US-Thailand (1962)}

Since the 1954 Manila Pact of the SEATO, both the US and Thailand have maintained their security alliance. The Thanat-Rusk Communique of 1962 is the basis of both nations' ongoing military ties. ${ }^{37}$ In 2003, Thailand was designated a major nonNATO ally. Thailand is a participant in the International Military Education and Training program and has received much defense material from the US. ${ }^{38}$

pdf (last visited on Oct. 30, 2015).

30 Supra note 15 , at 9 .

$31 \quad I d$.

32 Id. at 23-6.

33 See Treaty of Mutual Cooperation and Security between Japan and the United State of America of 1960 (Japan-US Security Treaty), available at http://www.mofa.go.jp/region/n-america/us/q\&a/ref/1.html; Security Treaty between the United States and Japan of 1951, available at http://avalon.law.yale.edu/20th_century/japan001.asp (all last visited on Oct. 30, 2015).

34 Japan-US Security Treaty art. 5.

35 Id. art. 3.

36 See U.S. Collective Defense Arrangements, available at http://www.state.gov/s///treaty/collectivedefense. For details, see E. Chanlett-Avery \& I. Rinehart, The U.S.-Japan Alliance, CRS Report RL33740 (Dec. 12, 2013), available at https://www.fas.org/sgp/crs/row/RL33740.pdf (last visited on Oct. 30, 2015).

37 Supra note 15 , at 23.

38 For details, see E. Chanlett-Avery, Thailand: Background and U.S. Relations, CRS Report RL32593, available at https://www.fas.org/sgp/crs/row/RL32593.pdf (last visited on Oct. 30, 2015). 


\section{Post-Cold War Platform}

With the end of the Cold War, these strategic ties were once more strengthened. However, things have drastically changed since the mid-2000s. The US was losing its status of "the only superpower," which had been given for a short period of time after the Cold War mainly because of the US economic depression and the fast rise of China. Thus, the US has been trying to set up another strategic partnership covering the whole Pacific coast called the TPP. This new initiative would establish not only economic cooperation, including trade and investment, but also a kind of security alliance of the US against China under the post-Cold War bipolar system.

\section{The New US Strategic Alliance Initiative: Trans-Pacific Partnership}

\section{A. Background: New Bipolar System (G2)}

The US supremacy was greatly strengthened shortly after the end of the Cold War primarily because the socialist regimes in Eastern Europe had been demolished following the dissolution of the Soviet Union. The US was solely leading the whole globe as "the only superpower," a first in human history. ${ }^{39}$ However, post-Cold War American supremacy was gradually declining after the September 11 attack. There were two reasons for this. First, the Bush administration was too involved in the "war on terror"; it spent more money than the country could sustain on the war against Iraq and Afghanistan. ${ }^{40}$ Such gigantic military expenditures were rapidly leading to economic depression. According to the dollar index, in 2011, the US dollar was approximately 32 percent devaluated from that of 1973 and nearly 50 percent down from 2003 (Figure 3). It goes without saying that this rapid devaluation of the US dollar had a strong hostile impact on the American dominance over world politics. Without currency competitiveness, the hegemonic country could neither fully open her market, nor defend the physical security of her allies. Consequently, the partners of the containment in East Asia began leaving the US-led security alliance.

39 For details, see Vojtech Mastny, Superpower Diplomacy, Encyclopedia of New American Nation, available at http:// www.americanforeignrelations.com/O-W/Superpower-Diplomacy.html (last visited on Oct. 30, 2015).

40 Since 9/11, the US Congress approved USD 1.6 trillion for the war on terror (as of Jan. 1, 2014). See Amy Belasco, The Cost of Iraq, Afghanistan, and Other Global War on Terror Operations since 9/11, CRS Report RL33110 (Dec. 8, 2014), available at $\mathrm{https}$ ://www.fas.org/sgp/crs/natsec/RL33110.pdf (last visited on Oct. 30, 2015). 
Figure 3: US Dollar Index from 1973 to $2012^{41}$

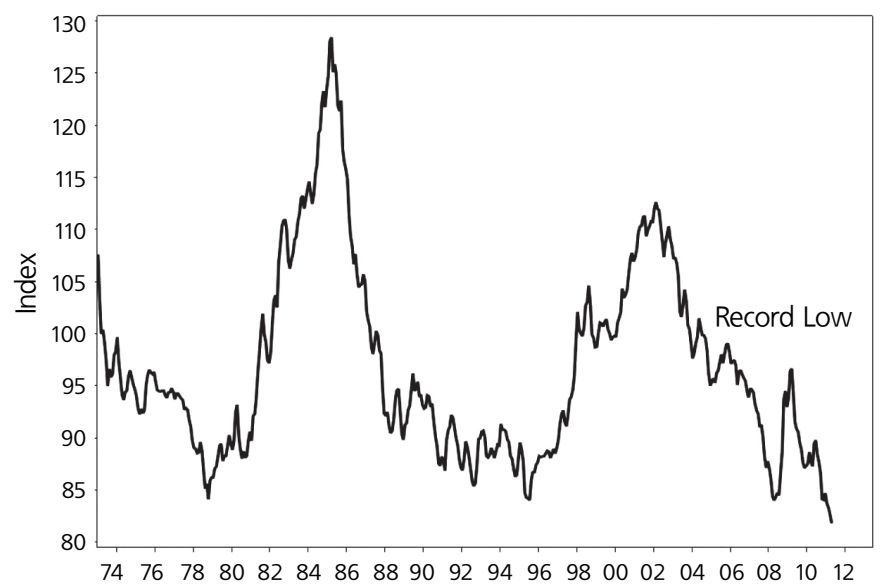

Second, China's economy has been growing so rapidly that her GDP is expected to surpass that of the US within a few years (Figure 4). China is becoming more influential on neighboring countries than before. E.g., China has become the largest trading partner of Korea; the trade volume of Korea with China is bigger than that with the US and Japan altogether. ${ }^{42}$ They finally signed the FTA on November 10, 2014. ${ }^{43}$ As the Chinese economic and political influence is increasing, the conventional security alliance led by the US is weakening in East Asia. This has finally brought about the containment crisis in this region.

41 J. Jones, Dollar Crashes to Record Low, Investment Research since 1978, Apr. 21, 2011, available at http://www. youngresearch.com/authors/dollar-crashes-to-record-low. In 2015, the US Dollar Index shows around 95. For details, see U.S. Dollar Historical Chart, available at http://www.macrotrends.net/1329/us-dollar-index-historical-chart (all last visited on Oct. 30, 2015).

42 Korean exports to China amount to 132,137 million dollars and imports from China amount to 81,461 million dollars a month (Nov. 2014). To the US, Korean exports amount to 64,089 million dollars, and the imports amount to 41,408 million dollars. To Japan, Korean exports amount to 29,831 million dollars, and the imports amount to 49,313 million dollars a month (Nov. 2014). See Kistat, available at http://stat.kita.net/stat/kts/ctr/CtrTotalImpExpList.screen (last visited on Oct. 30, 2015).

43 Chung-un Cho, Korea, China conclude FTA deal - Park, Xi agrees to urge N.K. to abandon nuke, Korea Herald, Nov. 10, 2014, available at http://www.koreaherald.com/view.php?ud=20141110001175. See also Korea, China agree to sign FTA, Korea Times, Nov. 10, 2014, available at http://www.koreatimes.co.kr/www/news/nation/2014/11/120_167854. html (all last visited on Oct. 30, 2015). 
Figure 4: Future GDP of China-US ${ }^{44}$

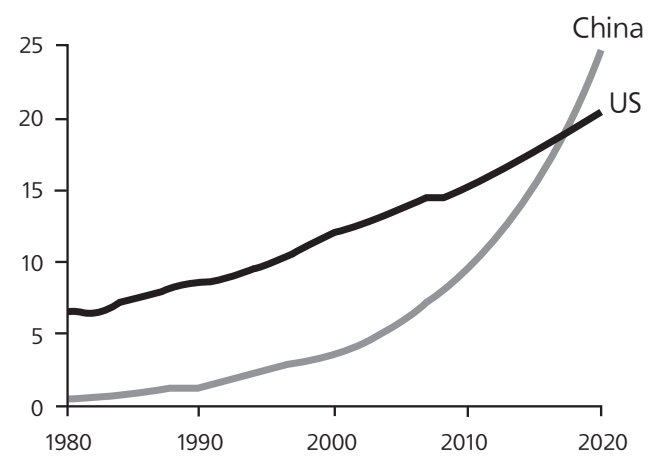

\section{B. Building}

\section{Overview}

At this historical turning point, TPP negotiations have been started. The TPP is a comprehensive trade and investment agreement throughout the Asia-Pacific region. ${ }^{45}$ The TPP addresses not only new and traditional trade issues in the region, but also a macro-plan for a collective strategic alliance initiative to control the postCold War bipolar system.

The TPP was originally proposed in 2005 as the Trans-Pacific Strategic Partnership Agreement ("TPSEP" or P4) between Brunei, Chile, New Zealand, and Singapore, which entered into force in $2006 .{ }^{46}$ In November 2011, the TPP leaders stated their common vision as follows:

We are confident that this agreement will be a model for ambition for other free trade agreements in the future, forging close linkages among our economies, enhancing our competitiveness, benefitting our consumers and supporting the creation and retention

44 B. Conerly, When Will China Be Larger than the U.S. Economy? Businomics Blog, Jan. 7, 2010, available at http:// businomics.typepad.com/businomics_blog/2010/01/when-will-china-be-larger-than-the-us-economy.html (last visited on Oct. 30, 2015).

45 I. Fergusson, M. McMinimy \& B. Williams, The Trans-Pacific Partnership (TPP) Negotiations and Issues for Congress, CRS Report R42694 (Nov. 19, 2014), at 1, available at https://www.fas.org/sgp/crs/row/R42694.pdf (last visited on Oct. 30, 2015).

46 See Overview of Trans-Pacific SEP, available at http://www.fta.gov.sg/fta_tpfta.asp?hl=12 (last visited on Oct. 30, 2015). 
of jobs, higher living standards, and the reduction of poverty in our countries. ${ }^{47}$

As of 2014, twelve countries throughout the Asia-Pacific region have participated in TPP negotiations such as Australia, Brunei, Canada, Chile, Japan, Malaysia, Mexico, New Zealand, Peru, Singapore, the US, and Vietnam. ${ }^{48}$ They are spread out in vast regions along the Pacific Ocean coast. Figure 5 shows the participating States and their economic and social capacity.

Figure 5: TPP Participating States and their Economic and Social Capacity $(2014)^{49}$

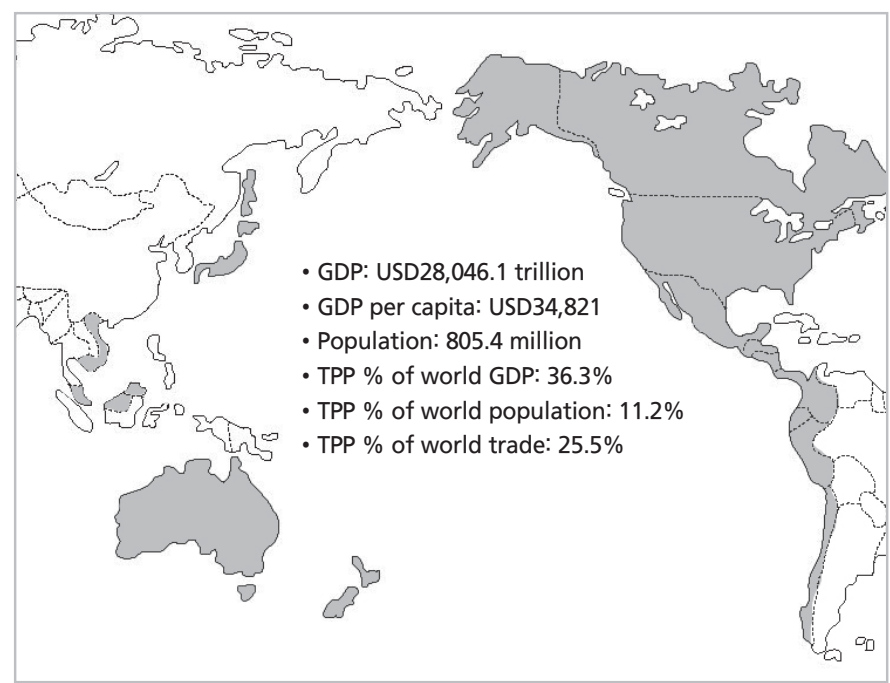

\section{Covered Areas}

The TPP covers almost all the areas regarding trade and investment. Table 1 shows the concrete areas of the TPP.

47 See Trans-Pacific Leaders Statement, available at http://www.ustr.gov/about-us/press-office/press-releases/2011/ november/trans-pacific-partnership-leaders-statement (last visited on Oct. 30, 2015).

48 Furthermore, South Korea, the Philippines, Laos, Colombia, Indonesia, Cambodia, and Taiwan are interested in participating in the TPP.

49 See Trans-Pacific Partnership Agreement negotiations, available at $\mathrm{http}: / /$ dfat.gov.au/trade/agreements/tpp/Pages/transpacific-partnership-agreement-tpp.aspx (last visited on Oct. 30, 2015). 
Table 1: Main Areas of the TPP 50

\begin{tabular}{|l|l|}
\hline Categories & \multicolumn{1}{|c|}{ Areas } \\
\hline \multirow{4}{*}{ Goods } & Trade in Goods \\
& Trade Remedies \\
& Customs Cooperation \\
& Rules of Origin \\
& Sanitary and Phytosanitary Measures \\
& Technical Barriers to Trade \\
& Market Access \\
\hline \multirow{5}{*}{ Services } & Cross-Border Trade in Services \\
& Financial Services \\
& E-Commerce \\
& Telecommunications \\
& Temporary Entry for Business Persons \\
& Investment \\
& Intellectual Property \\
& Environment \\
& Labor \\
& Government Procurement \\
& Legal and Institutional Issues \\
& Competition and State-Owned Enterprises \\
& Capacity Building \\
\hline
\end{tabular}

Horizontally, the TPP also deals with such topics as regulatory coherence, regional integration, transparency, and development. ${ }^{51}$

\section{Negotiations}

By August 2013, the participating countries had held the nineteenth round of negotiations since the first round in Melbourne in March 2010. ${ }^{52}$ They set the goal of wrapping up negotiations in 2012, but contentious issues, such as agriculture, intellectual property, services, and investments, have caused negotiations to continue into the present. ${ }^{53}$ Implementation of the TPP is one of the primary goals of the trade agenda of the Obama administration. In the Singapore meeting of 
May 2014, the ministers of the negotiating parties agreed to share views on what is needed to bring negotiations to a close and focus on making meaningful progress regarding market access; they also advanced outstanding rules issues in an effort to narrow the remaining differences. ${ }^{54}$ Annex 1 shows the content and processes of the negotiations.

After the nineteenth round, negotiations instead took the form of meetings among higher-level officials from representative countries. Within the period between August 2013 and October 2015 when the final deal was reached, there were around 20 meetings convened in various forms, such as Chief Negotiators' Meetings and Ministers' Meetings. The series of negotiations came to an end when the 12 representatives finally reached an agreement on October 5, 2015. ${ }^{55}$ Although the process of ratification in each country remains, the final agreement successfully outlined the largest trading block of history, which encompasses almost 40 percent of the global economy, including the largest and the third largest economies of the world - the US and Japan, respectively.

\section{Issues}

It is known that New Zealand and Canada were in the middle of a heated debate regarding dairy exports. ${ }^{56}$ That is, while New Zealand-a major dairy exporterwanted other nations within the TPP to lower tariffs and quotas for their dairy exports, Canada, the US, and Japan refused to reduce their restrictions on diary imports. The dispute over dairy products was resolved at the last minute as Canada, according to The Wall Street Journal, made "a sensitive concession during its own election period" ${ }^{, 57}$ and New Zealand gained access to markets in Canada, the US, and elsewhere. $^{58}$

Another challenging issue was that of biologics, which are "advanced medicines

54 USTR, Joint Statement at the TPP Ministers' Meeting in Singapore, available at http://www.ustr.gov/about-us/pressoffice/press-releases/2014/May/Joint-Statement-at-the-TPP-Ministers-Meeting-in-Singapore (last visited on Oct. 30, 2015).

55 See TPP Fulltext, available at https:/ustr.gov/trade-agreements/free-trade-agreements/trans-pacific-partnership/tppfull-text (last visited on Nov. 15, 2015).

56 J. Calmes, Trans-Pacific Partnership Is Reached, but Faces Scrutiny in Congress, N.Y. Times, Oct. 5, 2015, available at http://www.nytimes.com/2015/10/06/business/trans-pacific-partnership-trade-deal-is-reached.html?_r=0 (last visited on Oct. 30, 2015).

57 W. Mauldin, U.S. Reaches Trans-Pacific Partnership Trade Deal with 11 Pacific Nations, Wall St. J., Oct. 5, 2015, available at http://www.wsj.com/articles/u-s-reaches-trade-deal-with-11-pacific-nations-1444046867 (last visited on Oct. 30, 2015).

58 Supra note 55. 
made from living organisms." ${ }^{, 59}$ Intensified contention over biologics flared as the US, which possesses an enormous amount of patented biologics and wants to foster innovation in the sector, demanded 12-year-long intellectual property protection for pharmaceuticals, whereas Australia and Peru wanted to limit the period of protection to five years. "The compromise set a mandatory minimum of five years, without setting a maximum" and left both sides victorious. ${ }^{60}$

Finally, in the last days of negotiation, the US and Japan made a concession on automobiles trade. As a result, the US promised to get rid of the levy on many auto parts, which has been 2.5 percent thus far, as soon as the TPP goes into effect. ${ }^{61}$ Both sides also agreed to "long periods before American tariffs on Japanese vehicles sold in the US [this country] are phased out - 30 years for trucks, 25 for autos. ${ }^{, 62}$

\section{Strategic Implications}

\section{1. "Pivot to Asia"}

The TPP would have implications in more than just multilateral trade agreements in the Asia-Pacific region. It has been increasingly recognized as of "vital strategic importance to the United States." "63 Such a consideration has been expressed by President Obama's "Pivot to Asia" doctrine. ${ }^{64}$

Traditionally, the main focus of American diplomacy was Europe. Recently, however, it is shifting to the Asia-Pacific region mainly due to its economic gravity. ${ }^{65}$ The TPP is viewed as an important element in the American "rebalancing toward Asia." $"$ Tom Dillon, National Security Advisor to President Obama, said the following in his speech to the Asia Society:

The centerpiece of our economic rebalancing is the Trans-Pacific Partnership (TPP) - a

59 Id.

$60 \quad$ Id.

61 Yoko Kubota \& E. Pfanner, Japan's Car Makers Embrace Trans-Pacific Partnership, Wall St. J., Oct. 6, 2015, available at http://www.wsj.com/articles/japans-car-makers-embrace-trans-pacific-partnership-1444114976 (last visited on Oct. 30, 2015).

62 Supra note 56.

63 Supra note 45 , at 9

64 M. Manyin et al., Pivot to the Pacific? The Obama Administration's "Rebalancing” toward Asia, CRS Report R42448 (Mar. 28, 2012), at 7 (Table 1: Regional Shares of US Merchandise Trade), available at https://www.fas.org/sgp/ crs/natsec/R42448.pdf. For details, see USTR, Overview of TPP (American Competitiveness in the Asia-Pacific), available at http://www.ustr.gov/tpp/overview-of-the-TPP (all last visited on Oct. 30, 2015).

65 Manyin, id. at 20-1.

66 Supra note 45 , at 9. 
high-standard agreement the US is crafting with Asia-Pacific economies from Chile and Peru to New Zealand and Singapore. [...] We always envisioned the TPP as a growing platform for regional economic integration... Together, these eleven countries represent an annual trading relationship of $\$ 1.4$ trillion. The growing TPP is already a major step toward APEC's vision of a region-wide Free Trade Area of the Asia-Pacific. ${ }^{67}$

On the American rebalancing toward Asia, Dillon also maintained that:

It is a definitive statement of U.S. policy in the region; a clarion call for freedom; and yet another example of how, when it comes to the Asia-Pacific, the US is "all in." [...] To pursue this vision, the US is implementing a comprehensive, multidimensional strategy: strengthening alliances; deepening partnerships with emerging powers; building a stable, productive, and constructive relationship with China; empowering regional institutions; and helping to build a regional economic architecture that can sustain shared prosperity. These are the pillars of the U.S. strategy, and rebalancing means devoting the time, effort and resources necessary to get each one right. ${ }^{68}$

Such a sudden doctrine shift is mainly due to the escalating economic importance of the Asia-Pacific region, as the region is expected to cover more than 60 percent of all US commercial trade. ${ }^{69}$ The Obama administration also implemented its rebalancing policy toward the Asia-Pacific through military expenditure. In addition to the new US deployments to Australia and Singapore, administration officials have announced they will "of necessity rebalance [the US military] toward the AsiaPacific region." ${ }^{, 70}$ President Obama emphasized this point during his November 2011 speech to the Australian Parliament:

As we end today's wars, I have directed my national security team to make our presence and mission in the Asia Pacific a top priority. As a result, reductions in U.S. defense spending will not - I repeat, will not - come at the expense of the Asia Pacific. ${ }^{71}$

67 T. Dillon, The US and the Asia-Pacific in 2013, The Asia Society, New York, Mar. 11, 2013, available at http://www. whitehouse.gov/the-press-office/2013/03/11/remarks-tom-donilon-national-security-advisory-president-united-states-a (last visited on Oct. 30, 2015).

68 Id.

69 Supra note 57 , at 26 (Table A-1).

70 Department of Defense, Sustaining U.S. Global Leadership: Priorities for 21st Century Defense, Jan. 2012, at 2,

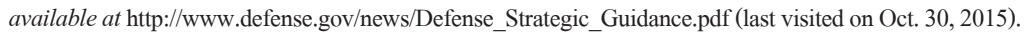

71 See Texts of remarks by President Obama to the Australian Parliament, Nov. 17, 2011, available at http://www. whitehouse.gov/the-press-office/2011/11/17/remarks-president-obama-australian-parliament (last visited on Oct. 30, 2015). 
The US may expect that, in the Asia-Pacific region, the TPP will provide new market access for American goods and services, strong and enforceable labor standards and environmental commitments, groundbreaking new rules on state-owned enterprises, a robust and balanced intellectual property rights framework, and a thriving digital economy. $^{72}$

\section{After 2017}

The ratification of TPP trade talks is expected to be an important issue for the 2016 US presidential candidates. Major candidates from both parties are maintaining different positions regarding the TPP.

Table 2: US Presidential Candidates' Views on TPP

\begin{tabular}{|l|l|l|l|}
\hline \multicolumn{2}{|c|}{ DEMOCRATS } & \multicolumn{2}{c|}{ REPUBLICANS } \\
\hline $\begin{array}{l}\text { Hillary } \\
\text { Clinton }\end{array}$ & $\begin{array}{l}\text { Clinton said she does not support the } \\
\text { TPP trade deal, putting her at odds } \\
\text { with President Barack Obama and his } \\
\text { administration. In an interview with } \\
\text { PBS NewsHour, she said that the deal } \\
\text { would not do enough to create jobs, } \\
\text { raise wages for Americans and advance } \\
\text { national security.73 }\end{array}$ & $\begin{array}{l}\text { Jeb } \\
\text { Bush }\end{array}$ & $\begin{array}{l}\text { Tush expressed his support for the } \\
\text { "I agree with what Hillary Clinton } \\
\text { said about TPP in 2012...,74 }\end{array}$ \\
\hline Bernie \\
Sanders & $\begin{array}{l}\text { Sander maintains that the TPP is a } \\
\text { disastrous trade agreement designed } \\
\text { to protect the interests of the largest } \\
\text { multi-national corporations at the } \\
\text { expense of workers, consumers, the } \\
\text { environment, and the foundations } \\
\text { of American democracy. It will } \\
\text { also negatively impact some of the } \\
\text { poorest people in the world.75 }\end{array}$ & $\begin{array}{l}\text { Chris } \\
\text { Christie }\end{array}$ & $\begin{array}{l}\text { Christie said that the TPP would } \\
\text { be good, not only for the US, but for } \\
\text { the other countries that we engage } \\
\text { in the partnership with. He said, } \\
\text { "I have real concerns about this } \\
\text { president's ability to negotiate } \\
\text { anything that represents a great } \\
\text { deal for America.,76 }\end{array}$ \\
\hline
\end{tabular}

72 USTR, Trans-Pacific Partnership, available at http://www.ustr.gov/tpp (last visited on Oct. 30, 2015).

73 See 2016 presidential Candidates on the Trans-Pacific Partnership trade deal: On the campaign trail, BALLOTPEDIA: The Free Encyclopedia of American Politics, available at http://ballotpedia.org/2016_presidential_candidates on_the_Trans-Pacific_Partnership_trade_deal (last visited on Oct. 30, 2015).

74 Id.

75 See Senator Bernie Sanders: The trans-pacific trade (TPP) agreement must be defeated, Huff Post, May 21, 2015, available at $\mathrm{http}: / / \mathrm{www}$.huffingtonpost.com/rep-bernie-sanders/the-tpp-must-be-defeated_b_7352166.html (last visited on Oct. 30, 2015).

76 Id. 


\begin{tabular}{|c|c|c|c|}
\hline $\begin{array}{l}\text { Lincoln } \\
\text { Chafee }\end{array}$ & $\begin{array}{l}\text { Chafee approves of the Trans-Pacific } \\
\text { Partnership. In a } 2013 \text { letter, Chafee } \\
\text { joined } 14 \text { other governors in urging } \\
\text { President Obama and congressional } \\
\text { leadership to support a Trans-Pacific } \\
\text { Partnership agreement, as well as } \\
\text { other international trade questions. }\end{array}$ & $\begin{array}{l}\text { Carly } \\
\text { Fiorina }\end{array}$ & $\begin{array}{l}\text { Fiorina believes that free and fair } \\
\text { trade would be an advantage } \\
\text { for the US. However, she is very } \\
\text { uncomfortable with this deal. }\end{array}$ \\
\hline $\begin{array}{l}\text { Martin } \\
\text { O'Malley }\end{array}$ & $\begin{array}{l}\text { O'Malley denounced the Trans-Pacific } \\
\text { Partnership as a "bad trade deal" } \\
\text { during a speech at Harvard's Institute } \\
\text { of Politics in which he outlined his } \\
\text { economic priorities for the country. }\end{array}$ & $\begin{array}{l}\text { Donald } \\
\text { Trump }\end{array}$ & $\begin{array}{l}\text { Trump slammed the Obama } \\
\text { administration over its Trans-Pacific } \\
\text { Partnership trade deal, labeling it } \\
\text { disastrous and warning that it } \\
\text { will encourage US companies to } \\
\text { slash domestic jobs. }{ }^{80}\end{array}$ \\
\hline
\end{tabular}

On October 7, 2015, Hilary Clinton said she would not support the TPP trade deal, putting her at odds with President Barack Obama and his administration. She said that the deal would not do enough to create jobs, raise wages for Americans, and advance national security. Jeb Bush expressed his support for the TPP. On April 22, 2015, Bush said he agrees "with what Hillary Clinton said about TPP in 2012: This is a great deal for America." 81

Hilary Clinton and Bernie Sanders are on opposite sides regarding the TPP. Former Maryland governor Martin O'Malley opposes the agreement. ${ }^{82}$ Donald Trump criticized the Obama administration over its TPP trade deal, labeling it disastrous. He also warned that it would encourage the American companies to slash domestic jobs. He said: "They don't talk about currency manipulation."

In addition, the TPP should receive the consent of the US Senate. As of 2015, the Senate is composed of 54 (Republican), 44 (Democratic), and 2 (Independent) seats. In November 2016, 34 senators will be newly elected, replacing the current members.

77 P. Key, Christie: No 'trust' for Obama with Trade Promotion Authority, BreItBart, June 11, 2015, available at http:// www.breitbart.com/video/2015/06/11/christie-no-trust-for-obama-with-trade-promotion-authority (last visited on Oct. 30, 2015).

78 PBS NewsHour "2016 Candidate Stands" series, June 3, 2015.

79 A. Griswold, Fiorina Comes Out against TPP: 'I Am Very Uncomfortable with This Deal,' DaILy CALLer, July 5, 2015, available at http://dailycaller.com/2015/05/07/fiorina-comes-out-against-tpp-i-am-very-uncomfortable-with-this-dealvideo (last visited on Oct. 30, 2015).

80 TPP trade deal 'a disaster,' other countries will 'dupe' US - Donald Trump, rt.com, May 11, 2015, available at https:// www.rt.com/usa/257377-tpp-deal-trump-criticism (last visited on Oct. 30, 2015).

81 Supra note 73.

82 R. Kaplan, The Democrats' internal battle over free Trade, CBS News, Apr. 23, 2015, available at http://www. cbsnews.com/news/democrats-free-trade-war (last visited on Oct. 30, 2015).

83 Supra note 80. 
In addition to the Presidential campaign, American people will keep their eyes on the TPP issue in this off-year election because the two major parties have generally maintained a different position to the Partnership. ${ }^{84}$

\section{China's Counter-Strategies against the New American Containment}

\section{A. US vs. China}

President Obama decided to redeploy 60 percent of American air and sea power to Asia by 2020 in order to counter the "aggressive, hegemonic, expansionist China." 85 China is worried about these new developments. In China's view, the US has always been concerned primarily with protecting its own global dominance in this region. ${ }^{86}$ Actually, the US lost its super hegemonic status due to the global financial crisis, while China became the world's second-largest economy in $2010 .^{87}$ Beijing is concerned about Washington's active stance on postponing the day when China's GDP finally surpasses that of the US. ${ }^{88}$ For Americans, the TPP would be an efficient measure for reducing the influence of China's currency unit, the Renminbi (CNY). ${ }^{89}$ Otherwise, the US-led security alliance could be broken in East Asia.

\section{B. One Belt, One Road Initiatives}

As a counter-measure against the US-led TPP, China launched "The One Belt, One Road Initiatives" (hereinafter Initiatives or "OBOR”). ${ }^{90}$ The Initiatives refer to the projects for building the Silk Road Economic Belt and the 21st-Century Maritime

84 E. Bradner, Obama's trade legacy hurdles: 2016 trail, Congress, CNN Politics, Oct. 6, 2015, available at http:// edition.cnn.com/2015/10/05/politics/tpp-trade-deal-obama-reaction-politics (last visited on Oct. 30, 2015).

85 S. Harner, The NYTimes' 'China Threat' Myth, The 'Pivot To Asia, 'and Obama's Foreign Policy Legacy, Forbes AsIA, June 22, 2014, available at http://www.forbes.com/sites/stephenharner/2014/06/22/the-nytimes-china-threat-myth-thepivot-to-asia-and-obamas-foreign-policy-legacy (last visited on Oct. 30, 2015).

86 For details on the Chinese viewpoint on the US Asia policy, see Dong Chen, Who Threatens Whom? The Chinese Threat and the Bush Doctrine, 7 J. EAST AsIA \& INT'L L. 39-44 (2014).

87 K. Lieberthal, The American Pivot to Asia, ForeIGn PoL'y, Dec. 21, 2011, available at http://www.foreignpolicy.com/ articles/2011/12/21/the_american_pivot_to_asia (last visited on Oct. 30, 2015).

88 Id.

89 Id.

90 See Xi's Strategic Conception of 'One Belt and One Road' Has Great Significance, CRIENGLISH.com News, Oct. 11, 2014, available at http://english.cri.cn/12394/2014/10/11/53s847421.htm (last visited on Oct. 30, 2015). 
Silk Road. ${ }^{11}$ (Figure 6) These are composed of a land-based belt from China via Central Asia and Russia to Europe and a maritime path through the Malacca strait to India, the Middle East, and East Africa, which will create trade and investment opportunities in infrastructure and construction, including transportation, ports, pipelines, power generation, and environmental projects, as well as stimulate energy and resource exchanges, consumption, and tourism. ${ }^{92}$

Figure 6: One Belt, One Road Initiative of China ${ }^{93}$

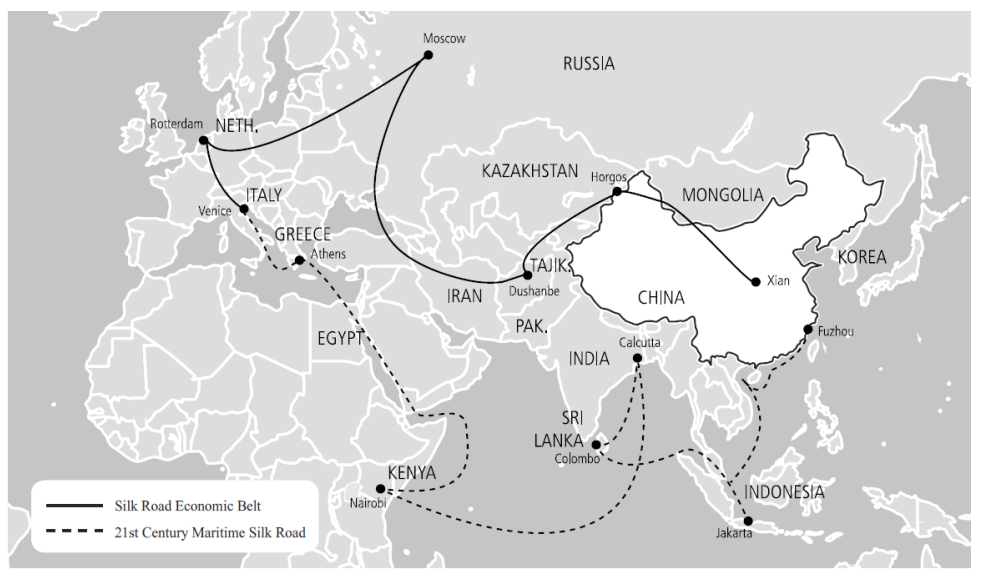

On March 28, 2015, the National Development and Reform Commission ("NDRC"), Ministry of Foreign Affairs ("MFA"), and Ministry of Commerce ("MOC") jointly released the "Vision and Actions on Jointly Building the Silk Road Economic Belt and the 21st-Century Maritime Silk Road" to set forth the general guidance and strategic principle of the "One Belt, One Road" Initiatives. Subsequently, the State Administration of Taxation ("SAT") released the "Notice Regarding the Tax Services and Administration to Implement the Development Strategy of the OBOR (Circular 60 ) to put forward a set of tax services and provide requirements of improving tax

91 See China's Belt and Road Initiatives open to world: Expert, XINHUANET, available at http://news.xinhuanet.com/ english/indepth/2014-12/04/c_133832704.htm (last visited on Oct. 30, 2015). See also Xiangqian Gong, Building of the New Maritime Silk Road: Its Constraints and Prospects, 7 J. EAST AsIA \& INT’L L. 235-42 (2014).

92 See News Analysis: Profound regional impact from China's Silk Road initiatives, XINHUANET, Nov. 19, 2014, available at http://news.xinhuanet.com/english/china/2014-11/19/c_133800737.htm (last visited on Oct. 30, 2015).

93 Bomin Ko, Uneasy Days of Push-and-Pull between China and the WTO: Recent Issues of China in the WTO, 1 ChIna \& WTO Rev. 114, Figure 1 (2015). 
administration connected with the "One Belt One Road" strategy."

\section{Asian Infrastructure Investment Bank}

The Asian Infrastructure Investment Bank (“AIIB”) was first shaped by China's proposal to spearhead global finance, which had been dominated by the US, Europe, and Japan. ${ }^{95}$ China is trying to perform this grand design as a comprehensive strategy in other ways. China provided USD 50 billion, half of the gross capital of the AIIB. On October 24, 2014, 21 States signed the agreement in Beijing recognizing the establishment of the Bank. ${ }^{96}$ In addition, Chinese President Xi Jinping announced on November 8, 2014, that China would set up a Silk Road fund worth USD 40 billion to support infrastructure, resources, industrial and financial cooperation, and other projects related to connectivity for countries along with the Initiatives. ${ }^{97}$

On June 29, 2015, representatives from the 57 Prospective Founding Members ("PFMs") gathered at a Signing Ceremony of the Bank's Articles of Agreement, and 50 PFMs signed the Articles. ${ }^{98}$ The 57 PFMs can become Founding Members by signing the Articles of Agreement in 2015 and ratifying the Articles of Agreement in 2015 or 2016. As of October 2015, 52 States have signed the Articles, two of which have ratified them. The Articles remain open for signing by PFMs until December 31,2015 ; it is expected that the AIIB will be operational by the end of the year. ${ }^{99}$

\section{Free Trade Area of the Asia-Pacific}

China is also taking the lead in building the Free Trade Area of the Asia-Pacific ("FTAAP"), an international trade pact backed by China and the Asia-Pacific

94 See SAT released new measures to support the "One Belt One Road" strategy, 20 China TAX/Business News Flash, May 2015, available at http://www.pwccn.com/home/eng/chinatax_news_may2015_20.html (last visited on Oct. 30, 2015).

95 S.R., Why China is creating a new "World Bank" for Asia, Economist, Nov. 11, 2014, available at http://www. economist.com/blogs/economist-explains/2014/11/economist-explains-6 (last visited on Oct. 30, 2015).

96 China, India, Thailand, Malaysia, Singapore, the Philippines, Pakistan, Bangladesh, Brunei, Cambodia, Kazakhstan, Kuwait, Laos, Myanmar, Mongolia, Nepal, Oman, Qatar, Sri Lanka, Uzbekistan, and Vietnam. See China launches AIIB in Asia to counter World Bank, ReUTERs, Oct. 24, 2014, available at http://www.affairscloud.com/china-launchesaiib-in-asia-to-counter-world-bank (last visited on Oct. 30, 2015).

97 Ben Guo, Profound regional impact from China's Silk Road initiatives, XINHUANET, Nov. 19, 2014, available at http:// www.china.org.cn/opinion/2014-11/19/content_34102349.htm (last visited on Oct. 30, 2015).

98 AIIB, Articles of Agreement, available at http://www.aiibank.org (last visited on Oct. 30, 2015). For details, see Woongjee Song, The Dilemma of Twenty-Six Percent: Enough to Challenge the System, 1 ChInA \& WTO Rev. 293-7 (2015).

99 AIIB, What is the Asian Infrastructure Investment Bank?, available at http://www.aiibank.org (last visited on Oct. 30, 2015). 
Economic Cooperation (“APEC"). ${ }^{100}$ Initiated in the APEC Summit in Hanoi, in 2006, the idea of FTAAP was developed with the failure of the WTO Doha Round. On November 11, 2014, the roadmap for the FTAAP was adopted at the 22nd APEC Summit in Beijing. ${ }^{101}$

\section{E. Regional Comprehensive Economic Partnership}

Another tool of China is the Regional Comprehensive Economic Partnership ("RCEP"), which is a mega RTA between ten ASEAN member States and six States with which the ASEAN has existing FTAs (Australia, China, India, Japan, South Korea, and New Zealand). ${ }^{102}$ The RCEP covers trade in goods, trade in services, investment, economic and technical cooperation, intellectual property, competition, dispute settlement, and other issues. ${ }^{103}$ Formally launched in November 2012 at the ASEAN Summit in Cambodia, ${ }^{104}$ the RCEP includes more than three billion people (about 45 percent of the world's population), with a combined GDP of more than USD 17 trillion (approximately a third of the world's annual GDP for 2012). ${ }^{105}$

Ten rounds of RCEP negotiations have already been held. In the ninth round, officials of the 16 RCEP members met from 1 to 7 August 2015 in Nay Pyi Taw, Burma. Following the productive Intersessional RCEP Ministerial meetings and ahead of the Third RCEP Ministerial meeting (August 24 in Malaysia), officials commenced market access negotiations on services, with all countries having submitted their initial services offers. Fourteen countries have submitted investment reservation lists. The Working Group on Electronic Commerce met for the first time. On October 16, 2015, the tenth round was completed in Pusan, Korea, where representatives from 16 countries negotiated on practical market access. ${ }^{106}$ The RCEP

100 R. Scollay, A Free Trade Area of the Asia Pacific (FTAAP)? Rationale and Feasibility, Proceedings of ISEAS Seminar, Singapore, 2007, available at http://www.pecc.org/resources/publications/trade-and-investment/2028-a-free-trade-areaof-the-asia-pacific-ftaap-rationale-and-feasibility (last visited on Oct. 30, 2015).

101 See Joint Ministerial Statement of 2014 APEC Ministerial Meeting, Nov. 8, 2014, available at http://www.apec.org/ Meeting-Papers/Ministerial-Statements/Annual/2014/2014_amm.aspx; 2014 APEC draws roadmap for region, Dec. 7, 2014, available at $\mathrm{http}: / 38.83 .102 .134: 81 /$ epaper/zsjxsbd/2014/11/20/A01/story/1414604.shtml (all last visited on Oct. 30, 2015).

102 Ministry of Trade and Industry of Singapore, Fact Sheet on the Regional Comprehensive Economic Partnership, (2012 News), Nov. 2012, at 1, available at http://www.fta.gov.sg/press_home.asp (last visited on Oct. 30, 2015).

$103 I d$. at 2.

104 New Zealand Ministry of Foreign Affairs \& Trade Regional Comprehensive Economic Partnership, available at http:// www.mfat.govt.nz/Trade-and-Economic-Relations/2-Trade-Relationships-and-Agreements/RCEP (last visited on Oct. 30, 2015).

105 Supra note 102.

106 See 10th Round of RCEP Trade Talks Wrap, KBS WorLd RADIO, Oct. 17, 2015, available at http://world.kbs.co.kr/ 
is expected to compete with the TPP as a possible pathway to a free-trade area of the Asia-Pacific region. ${ }^{107}$

\section{F. Evaluation: It is China that Matters}

China's breathtaking economic development has led her to the hub of a wide range of economic and strategic ties that have been newly built in the new millennium. Such a network is a great challenge to the new economic integration and strategic alliance of the US mainly due to the TPP covering a broader range of countries along the Pacific coast in the twenty-first century. As of today, the US is trying to "share a commitment to concluding a high-standard, ambitious agreement and to expanding the initial group to include additional countries throughout the Asia-Pacific region." 108 The US expects to transplant the American standards to politics as well as economy among members. Moreover, they are planning to set up coalition networks of transaction, which would be further developed into a common strategic alliance regime in this region.

It is China that matters, however. The ultimate success of the TPP will depend on "proactive connection between G2." Such an upgraded 'strategic partnership,' which was never considered by the US until 2000, is now a critical ground for the economic prosperity and peaceful co-existence in the contemporary AsiaPacific region. Many countries are commonly tied with the economic and political institutions existing in this area led by the US and China, respectively. Table 3 shows that seven TPP member States have simultaneously joined the RCEP; in addition, all twelve TPP member States, including four countries who are trying to join the TPP (Indonesia, Korea, the Philippines, and Thailand) are members of the FTAAP. All of them are intermingled with bilateral or regional FTAs. E.g., Korea has concluded FTAs with both the US and China and is considering a trilateral FTA with China and Japan. Korea has also signed FTAs with ten (10) TPP members, including Australia, Canada, Chile, New Zealand, and Singapore. She will be required to exercise diplomatic leverage for coordinating hegemonic competition. In addition, China concluded a FTA with Australia on November 17, 2014. ${ }^{109}$

english/news/news_Ec_detail.htm? No=114091 (last visited on Oct. 30, 2015).

107 See Regional Comprehensive Economic Partnership, Department of Foreign Affairs and Trade of Australia, available at http://www.dfat.gov.au (last visited on Oct. 30, 2015).

108 USTR, Overview of TPP (Leading Asia-Pacific Regional Integration Initiative), available at http://www.ustr.gov/tpp/ overview-of-the-TPP (last visited on Oct. 30, 2015).

109 Ministry of Foreign Affairs and Trade (Australia), Conclusion of ChAFTA negotiations, available at http://dfat.gov.au/ trade/agreements/chafta/news/Pages/conclusion-of-chafta-negotiations.aspx (last visited on Oct. 30, 2015). 
The containment is an old-fashioned relic of the Cold War. In Europe, containment is not needed anymore, while in East Asia, it is not yet insignificant. Both the Americans and the Chinese should recognize others in the world. In this course, their different approaches to international legal frameworks should be analyzed and coordinated.

Table 3: Parties to FTAAP, TPP, and RCEP ${ }^{110}$

\begin{tabular}{|c|c|c|c|}
\hline $\begin{array}{ll}\text { Countries } & \text { Agreements } \\
\end{array}$ & FTAAP & RCEP & TPP \\
\hline Australia & $\bullet$ & $\sqrt{ }$ & $\Delta$ \\
\hline Brunei Darussalam & $\bullet$ & $\sqrt{ }$ & $\Delta$ \\
\hline Cambodia & $\bullet$ & $\sqrt{ }$ & \\
\hline Canada & - & & $\Delta$ \\
\hline Chile & $\bullet$ & & $\Delta$ \\
\hline China, People's Republic & - & $\sqrt{ }$ & \\
\hline India & & $\sqrt{ }$ & \\
\hline Indonesia & $\bullet$ & $\sqrt{ }$ & \\
\hline Japan & $\bullet$ & $\sqrt{ }$ & $\Delta$ \\
\hline Korea, Republic of & $\bullet$ & $\sqrt{ }$ & \\
\hline Lao PDR & $\bullet$ & $\sqrt{ }$ & \\
\hline Malaysia & $\bullet$ & $\sqrt{ }$ & $\Delta$ \\
\hline Mexico & $\bullet$ & & $\Delta$ \\
\hline Myanmar & - & $\sqrt{ }$ & \\
\hline New Zealand & $\bullet$ & $\sqrt{ }$ & $\Delta$ \\
\hline Peru & $\bullet$ & & $\Delta$ \\
\hline Philippines & $\bullet$ & $\sqrt{ }$ & \\
\hline Russia & $\bullet$ & & \\
\hline Singapore & $\bullet$ & $\sqrt{ }$ & $\Delta$ \\
\hline Thailand & $\bullet$ & $\sqrt{ }$ & \\
\hline USA & $\bullet$ & & $\Delta$ \\
\hline Vietnam & $\bullet$ & $\sqrt{ }$ & $\Delta$ \\
\hline
\end{tabular}

Source: Compiled by the author.

110 M. Plummer, A vision of global free trade? The new regionalism and the 'building blocs' debate (Figure 1), AsIA Pathways, Dec. 10, 2013, available at http://www.asiapathways-adbi.org/2013/12/a-vision-of-global-free-tradethe-new-regionalism-and-the-building-blocs-debate, recited from P. Petri, M. Plummer \& F. Zhai, The TransPacific Partnership and Asia-Pacific Integration: A Quantitative Assessment (Policy Analyses in International ECONOMICS) 98 (2012) (last visited on Oct. 30, 2015). 


\section{Conclusion: Legal and Strategic Implications of TPP}

The rise of China is a trend of contemporary world politics as well as the global economy. The hegemony of China is changing everything, including the already established international legal order, which was based on long-lasting AngloAmerican dominance. During the Cold War period, the American security initiative was legally implemented mainly by defense pacts at two different regions of the globe: one was the NATO, which is a collective security treaty in Europe; the other was a group of bilateral defense treaties concluded with the allies along the coast of East Asia. In East Asia, each defense treaty has been connected as a defense belt whose main objective is to block China within her mainland (Containment Policy). The containment reflected an aspect of the US global strategies at the time of the Cold War, whose ultimate purpose was to maximize her economic profit in the global market based on political and military hegemony. It might be the most efficient measure for the US to dominate the world without historical and cultural alliances. International law at that time was shaped as such, reflecting the environment of the Cold War, which could be defined as "hostile co-existence."

The end of the Cold War has changed everything, however. A point of contention is China, whose economy and political influence are fast escalating. To the US, China may be a new threat after the Soviet Union. Furthermore, the US should compete in the energy and finance markets with the integrated Europe. While the US was conducting the "war on terror" in the Middle East, spending an astrological amount on military expenditure, China was developing her economy to rival the American influence in the Asia-Pacific region. The containment is no longer a fundamental ground of security in East Asia; the TPP has become an alternative replacing the old containment. The US has expanded TPP as a new international legal setting for the security alliance initiative along the pan-Pacific region. The US is willing to make the Partnership a "High-Standard Trade Framework" and "Better Structured [Alliance] Platform." "I11 Its main objective is to check and balance China's expansion to the Pacific area, which has been dominated by the US. Their hegemonic clash in this area had already begun, as shown by a number of on-going maritime conflicts in the South China Sea and East China Sea.

The TPP may be a double-edged sword under the new bipolar system. It lies

111 L. Li, Trans-Pacific Partnership Agreement: An Analysis of Opportunities and Challenges, May 7, 2012, at 13, available at $\mathrm{https} / / /$ www.claremontmckenna.edu/keck/../LiY\%20Fellowship\%20Paper.pdf (last visited on Oct. 30, 2015). 
between hostile competition and harmonized cooperation. In order to be a new international legal frame for peace in the time of the bipolar system, the TPP should be operated in a fair, open, and democratic manner. Its predictable legal setting is thus indispensable for the peaceful coordination of the competition between both sides. The TPP could be a firm ground for the stability of this region if the group of agreements share a vision of cooperation, not confrontation, in the future.

Annex 1: TPP Round of Negotiations

\begin{tabular}{|c|c|c|c|}
\hline Round & Date & Place & Content \\
\hline 1 & $\begin{array}{l}15-19 \\
\text { March } \\
2010\end{array}$ & $\begin{array}{l}\text { Melbourne, } \\
\text { Australia }\end{array}$ & $\begin{array}{l}\text { Included industrial goods, agriculture, sanitary and } \\
\text { phytosanitary standards, telecommunications, financial } \\
\text { services, customs, rules of origin, government procurement, } \\
\text { environment, and trade capacity building. }\end{array}$ \\
\hline 2 & $\begin{array}{l}14-18 \\
\text { June } \\
2010\end{array}$ & $\begin{array}{c}\text { San Francisco, } \\
\text { US }\end{array}$ & $\begin{array}{l}\text { Included "determining the architecture for market access } \\
\text { negotiations, deciding the relationship between the } \\
\text { TPP and existing FTAs among the negotiating partners, } \\
\text { addressing horizontal issues, such as small business } \\
\text { priorities, regulatory coherence, and other issues that } \\
\text { reflect the way businesses operate and workers interact in } \\
\text { the } 21 \text { st century, and proceeding toward the tabling of text } \\
\text { on all chapters of the agreement in the third negotiating } \\
\text { round, scheduled for October in Brunei." }\end{array}$ \\
\hline 3 & $\begin{array}{l}5-8 \\
\text { October } \\
2010\end{array}$ & Brunei & $\begin{array}{l}\text { This round included "meetings on agriculture, services, } \\
\text { investment, government procurement, competition, } \\
\text { environment, and labor. The groups focused on the } \\
\text { objectives that they had set for this round: preparation } \\
\text { of consolidated text and proposals for cooperation. } \\
\text { Negotiations will continue through Saturday, with groups } \\
\text { on telecommunications, e-commerce, textiles, customs, } \\
\text { technical barriers to trade, and trade capacity building } \\
\text { beginning Friday." }\end{array}$ \\
\hline 4 & $\begin{array}{l}6-10 \\
\text { December } \\
2010\end{array}$ & $\begin{array}{c}\text { Auckland, } \\
\text { New Zealand }\end{array}$ & $\begin{array}{l}\text { In the 4th round of talks, the negotiating countries "began } \\
\text { work on trade in goods, financial services, customs, labor, } \\
\text { and intellectual property. They also discussed cross- } \\
\text { cutting issues, including how to ensure that small- and } \\
\text { medium-sized enterprises can take advantage of the TPP, } \\
\text { promoting greater connectivity and the participation of } \\
\text { U.S. firms in Asia-Pacific supply chains and enhancing the } \\
\text { coherence of the regulatory systems of the TPP countries } \\
\text { to make trade across the region more seamless." }\end{array}$ \\
\hline
\end{tabular}




\begin{tabular}{|c|c|c|c|}
\hline 5 & $\begin{array}{c}14-18 \\
\text { February } \\
2011\end{array}$ & $\begin{array}{l}\text { Santiago, } \\
\text { Chile }\end{array}$ & $\begin{array}{l}\text { In Santiago, the negotiating countries "made further } \\
\text { progress in developing the agreement's legal texts, which } \\
\text { will spell out the rights and obligations each country } \\
\text { will take on and that will cover all aspects of trade and } \\
\text { investment relationships. The teams carefully reviewed } \\
\text { the text proposals made by each country, ensuring } \\
\text { understanding of each other's proposals so negotiations } \\
\text { could advance. With consolidated negotiating texts in most } \\
\text { areas, partners began seeking to narrow differences and to } \\
\text { consider the interests and concerns of each country." }\end{array}$ \\
\hline 6 & $\begin{array}{c}24 \text { March } \\
-1 \text { April } \\
2011\end{array}$ & Singapore & $\begin{array}{l}\text { In Singapore, "the US and TPP countries made substantial } \\
\text { headway toward a key goal of developing the legal texts } \\
\text { of the agreement, which include commitments covering } \\
\text { all aspects of their trade and investment relationship. } \\
\text { Recognizing the priority of this negotiation as well as } \\
\text { the challenge of negotiating a regional agreement with } \\
\text { nine countries, each country began showing the type of } \\
\text { flexibility that will be needed to successfully conclude the } \\
\text { negotiation. As a result, the teams were able to narrow the } \\
\text { gaps in their positions on a wide range of issues across the } \\
\text { more than } 25 \text { chapters of the agreement." }\end{array}$ \\
\hline 7 & $\begin{array}{l}15-24 \\
\text { June } \\
2011\end{array}$ & $\begin{array}{l}\text { Ho Chi } \\
\text { Minh City, } \\
\text { Vietnam }\end{array}$ & $\begin{array}{l}\text { In Vietnam, "among the issues on which the teams had } \\
\text { particularly productive discussions were the new cross- } \\
\text { cutting issues that will feature for the first time in the TPP. } \\
\text { After consulting internally on the U.S. text tabled at the } \\
\text { sixth round, they furthered their efforts to find common } \\
\text { ground on the regulatory coherence text intended to } \\
\text { make the regulatory systems of their countries operate } \\
\text { in a more consistent and seamless manner and avoid the } \\
\text { types of regulatory barriers that are increasingly among } \\
\text { the key obstacles to trade. The teams also had constructive } \\
\text { discussions on approaches to development in the TPP and } \\
\text { the importance of ensuring that the agreement serves to } \\
\text { close the development gap among TPP members." }\end{array}$ \\
\hline 8 & $\begin{array}{c}6-15 \\
\text { September } \\
2011\end{array}$ & $\begin{array}{c}\text { Chicago, } \\
\text { USA }\end{array}$ & $\begin{array}{l}\text { Negotiators from the nine TPP partner countries-Australia, } \\
\text { Brunei Darussalam, Chile, Malaysia, New Zealand, Peru, } \\
\text { Singapore, Vietnam, and the US-are reporting good progress } \\
\text { early in the eighth round of talks, which are expected to } \\
\text { last until September } 15 \text {. Negotiating groups that have } \\
\text { already begun meetings include services, financial services, } \\
\text { investment, customs, telecommunications, intellectual } \\
\text { property rights, government procurement, sanitary and } \\
\text { phytosanitary measures, and environment. Numerous } \\
\text { negotiating teams are also holding bilateral meetings. }\end{array}$ \\
\hline
\end{tabular}




\begin{tabular}{|c|c|c|c|}
\hline 9 & $\begin{array}{c}22-29 \\
\text { October } \\
2011\end{array}$ & Lima, Peru & $\begin{array}{l}\text { During this round, negotiators built upon progress made } \\
\text { in previous rounds and pressed forward toward the } \\
\text { goal of reaching the broad outlines of an ambitious, jobs- } \\
\text { focused agreement through the Asia-Pacific Economic } \\
\text { Cooperation Leaders' meeting in Honolulu, HI, next } \\
\text { month. At APEC, President Obama and his counterparts } \\
\text { from the other eight TPP countries will take stock of the } \\
\text { progress to date and discuss the next steps. }\end{array}$ \\
\hline 10 & $\begin{array}{c}5-9 \\
\text { December } \\
2011\end{array}$ & $\begin{array}{c}\text { Kuala Lumpur, } \\
\text { Malaysia }\end{array}$ & $\begin{array}{l}\text { The 10th round of negotiations continued the previously } \\
\text { started work and added issues that were not previously } \\
\text { addressed. The tariff packages on industrial goods, } \\
\text { agriculture and textiles, and emerging trade challenges, such } \\
\text { as cross-border trade in services, investment, intellectual } \\
\text { property rights, and rules of origin were discussed. }{ }^{112}\end{array}$ \\
\hline 11 & $\begin{array}{c}2-9 \\
\text { March } \\
2012\end{array}$ & $\begin{array}{c}\text { Melbourne, } \\
\text { Australia }\end{array}$ & $\begin{array}{l}\text { The 11th round negotiated "financial services, sanitary } \\
\text { and phytosanitary measures, legal issues, rules of origin, } \\
\text { environment, telecommunications, competition, non- } \\
\text { conforming measures, government procurement, intellectual } \\
\text { property rights, e-commerce, market access, customs issues, } \\
\text { temporary entry, regulatory cooperation and trade capacity } \\
\text { building."113 Approximately } 250 \text { stakeholders had the on- } \\
\text { site opportunity to share their views directly with the TPP } \\
\text { negotiating teams. }\end{array}$ \\
\hline 12 & $\begin{array}{l}8-18 \\
\text { May } \\
2012\end{array}$ & $\begin{array}{l}\text { Dallas, } \\
\text { USA }\end{array}$ & $\begin{array}{l}\text { Negotiations included market access, rules of origin, } \\
\text { environment, financial services, non-clearing members, } \\
\text { legal issues, sanitary and phytosanitary measures, } \\
\text { government procurement, labor, competition, investment, } \\
\text { technical barriers to trade, e-commerce, and trade capacity } \\
\text { building. Chief negotiators met several times. Negotiators } \\
\text { and stakeholders held face-to-face conversations and } \\
\text { shared their views on issues of interest and concern. }{ }^{114}\end{array}$ \\
\hline
\end{tabular}

112 Round 10: Kuala Lumpur, available at http://www.ustr.gov/round-10-kuala-lumpur (last visited on Oct. 30, 2015).

113 Round 11: Melbourne, available at http://www.ustr.gov/trade-agreements/free-trade-agreements/trans-pacificpartnership/round-11-melbourne (last visited on Oct. 30, 2015).

114 Round 12: Dallas, available at http://www.ustr.gov/trade-agreements/free-trade-agreements/trans-pacific-partnership/ round-12-dallas (last visited on Oct. 30, 2015). 


\begin{tabular}{|c|c|c|c|}
\hline 13 & $\begin{array}{l}2-10 \\
\text { July } \\
2012\end{array}$ & $\begin{array}{c}\text { San Diego, } \\
\text { USA }\end{array}$ & $\begin{array}{l}\text { Negotiators moved toward the conclusion of the more } \\
\text { than } 20 \text { chapters under negotiation and made progress } \\
\text { in a number of chapters, including customs, cross-border } \\
\text { services, telecommunications, government procurement, } \\
\text { competition policy, and cooperation and capacity building. } \\
\text { The negotiating groups moved their work forward in } \\
\text { other issues, including rules of origin, investment, financial } \\
\text { services, temporary entry, and other issues. Additionally, } \\
\text { USTR notified Congress of its intent to enter into TPP } \\
\text { negotiations with Mexico and Canada on July } 9 \text { and 10, } \\
\text { respectively. }\end{array}$ \\
\hline 14 & $\begin{array}{c}6-15 \\
\text { September } \\
2012\end{array}$ & $\begin{array}{l}\text { Leesburg, } \\
\text { USA }\end{array}$ & $\begin{array}{l}\text { Continuation of negotiations on various TPP issues, } \\
\text { meetings with more than } 450 \text { stakeholders, and various } \\
\text { bilateral meetings. }\end{array}$ \\
\hline 15 & $\begin{array}{c}3-12 \\
\text { December } \\
2012\end{array}$ & $\begin{array}{c}\text { Auckland, } \\
\text { New Zealand }\end{array}$ & $\begin{array}{l}\text { Canada and Mexico participated in the TPP negotiations } \\
\text { for the first time. Negotiators made progress toward } \\
\text { closing the legal texts of the } 29 \text { chapters of the agreement } \\
\text { covering all trade and investment-related issues. Leaders } \\
\text { of the } 11 \text { TPP countries have agreed to comprehensive } \\
\text { access to each other's markets in all areas. Negotiators also } \\
\text { met with } 300 \text { stakeholders. }{ }^{117}\end{array}$ \\
\hline 16 & $\begin{array}{l}4-13 \\
\text { March } \\
2013\end{array}$ & Singapore & $\begin{array}{l}\text { The negotiations were accelerated. The delegations } \\
\text { succeeded in finding solutions to issues such as customs, } \\
\text { telecommunications, investment, services, technical barriers } \\
\text { to trade, sanitary and phytosanitary measures, intellectual } \\
\text { property, regulatory coherence, and development. Negotiating } \\
\text { groups for customs, telecommunications, regulatory } \\
\text { coherence, and development will not meet again. }{ }^{118}\end{array}$ \\
\hline 17 & $\begin{array}{l}15-24 \\
\text { May } \\
2013\end{array}$ & $\begin{array}{l}\text { Lima, } \\
\text { Peru }\end{array}$ & $\begin{array}{l}\text { The following issues continued to be discussed: Non- } \\
\text { conforming measures, e-commerce, rules of origin, sanitary } \\
\text { and phytosanitary issues, legal issues, financial services, } \\
\text { and intellectual property rights issues. Meetings of Chief } \\
\text { Negotiators, bilateral meetings, and meetings with }>300 \\
\text { stakeholders were held. }{ }^{119}\end{array}$ \\
\hline
\end{tabular}

115 Round 13: San Diego, available at http://www.ustr.gov/trade-agreements/free-trade-agreements/trans-pacificpartnership/round-13-sandiego (last visited on Oct. 30, 2015).

116 Round 14: Leesburg, available at http://www.ustr.gov/trade-agreements/free-trade-agreements/trans-pacificpartnership/round-14-leesburg (last visited on Oct. 30, 2015).

117 Round 15: Auckland, New Zealand, available at http://www.ustr.gov/trade-agreements/free-trade-agreements/transpacific-partnership/round-15-newzealand (last visited on Oct. 30, 2015).

118 Round 16: Singapore, available at http://www.ustr.gov/trade-agreements/free-trade-agreements/trans-pacificpartnership/round-16-singapore (last visited on Oct. 30, 2015).

119 Round 17: Lima, Peru, available at http://www.ustr.gov/trade-agreements/free-trade-agreements/trans-pacificpartnership/round-17-peru (last visited on Oct. 30, 2015). 


\begin{tabular}{|c|c|c|c|}
\hline 18 & $\begin{array}{c}15-24 \\
\text { July } \\
2013\end{array}$ & $\begin{array}{c}\text { Kota Kinabalu, } \\
\text { Malaysia }\end{array}$ & $\begin{array}{l}\text { The negotiating groups covering market access, rules of } \\
\text { origin, technical barriers to trade, investment, financial } \\
\text { services, e-commerce, and transparency reached an } \\
\text { agreement. They also made progress in covering intellectual } \\
\text { property, competition, and environment; each group } \\
\text { developed a detailed plan for closing remaining issues and } \\
\text { completing their work. On July 23, Japan became the 12th } \\
\text { member of the negotiations. }{ }^{120}\end{array}$ \\
\hline 19 & $\begin{array}{c}\text { 23-30 } \\
\text { August } \\
2013\end{array}$ & $\begin{array}{l}\text { Bandar Seri } \\
\text { Begawan, } \\
\text { Brunei }\end{array}$ & $\begin{array}{l}\text { Negotiators advanced their work on the texts covering } \\
\text { market access, rules of origin, investment, financial services, } \\
\text { intellectual property, competition, and environment. } \\
\text { Several other negotiating groups did not meet during this } \\
\text { round because they required additional time for domestic } \\
\text { consultation. }{ }^{121} \text { Particular areas of focus included matters } \\
\text { related to market access for goods, services/investment, } \\
\text { financial services, and government procurement as well as } \\
\text { the texts covering intellectual property, competition, and } \\
\text { environmental issues. }{ }^{122}\end{array}$ \\
\hline
\end{tabular}

120 Round 18: Kota Kinabalu, Malaysia, available at http://www.ustr.gov/trade-agreements/free-trade-agreements/transpacific-partnership/round-18-malaysia (last visited on Oct. 30, 2015).

121 See Ministerial Guidance Energizes Negotiators' Work during 19th Round of TPP Negotiations, available at http:// www.ustr.gov/19th-TPP-Round-Summary (last visited on Oct. 30, 2015).

122 Joint Press Statement TPP Ministerial Meeting, Brunei Darussalam, Aug. 23, 2013, available at http://www.mfat.govt. $\mathrm{nz} /$ downloads/trade-agreement/transpacific/Joint\%20ministerial\%20statement.pdf (last visited on Oct. 30, 2015). 